Abstracta Iranica Abstracta Iranica

Revue bibliographique pour le domaine irano-aryen

Volume 31 | 2011

Comptes rendus des publications de 2008

\title{
Makhmalbaf at large, The making of a rebel filmmaker. London - New York, I.B. Tauris, 2008, XXXI-255 p.
}

\section{Poupak Rafii Nejad}

\section{(2) OpenEdition}

1 Journals

\section{Édition électronique}

URL : http://journals.openedition.org/abstractairanica/39847

DOI : 10.4000/abstractairanica.39847

ISSN : 1961-960X

Éditeur :

CNRS (UMR 7528 Mondes iraniens et indiens), Éditions de l'IFRI

\section{Édition imprimée}

Date de publication : 15 mai 2011

ISSN : 0240-8910

\section{Référence électronique}

Poupak Rafii Nejad, « Makhmalbaf at large, The making of a rebel filmmaker. London - New York, I.B. Tauris, 2008, XXXI-255 p. », Abstracta Iranica [En ligne], Volume 31 | 2011, document 311, mis en ligne le 11 octobre 2012, consulté le 27 septembre 2020. URL : http://journals.openedition.org/ abstractairanica/39847 ; DOI : https://doi.org/10.4000/abstractairanica.39847

Ce document a été généré automatiquement le 27 septembre 2020.

Tous droits réservés 


\title{
Makhmalbaf at large, The making of a rebel filmmaker. London - New York, I.B. Tauris, 2008, XXXI-255 p.
}

\author{
Poupak Rafii Nejad
}

Avec une préface du cinéaste, cet ouvrage est en quelque sorte un hommage rendu à MaḨmalbāf, ami et source d'inspiration pour Dabāšī, lui-même, auteur de nombreuses publications sur le cinéma iranien (voir notamment Abs. Ir. 30, c.r. n 369 et Abs. Ir. 23, c.r. $n^{\circ} 348$ ). L'A. essaie de démontrer à travers le parcours personnel et professionnel du cinéaste, son évolution et sa transformation: la métamorphose d'un musulman révolutionnaire et auteur d'un cinéma idéologique, en un " artiste humaniste ». Ce qui n'enlève rien à l'aspect paradoxal du personnage et à sa capacité de surprendre ses spectateurs. Au-delà de cette métamorphose, MaH̆malbāf reste ce qu'il est, c'est-à-dire un rebelle. Ce livre décrit aussi l'histoire d'une amitié entre deux passionnés du cinéma malgré leurs différences sur leurs engagements idéologico-politiques.

\section{INDEX}

Thèmes : 17.2. Arts du spectacle

\section{AUTEURS}

POUPAK RAFII NEJAD

CNRS - Mondes iranien et indien - Paris 